UNIVERSIDADE DE SÃO PAULO

FACULDADE DE EDUCAÇÃO

MICAL DE MELO MARCELINO MAGALHÃES

Subjetividade em advir: a construção da metáfora em textos de alunos da escola básica 
MICAL DE MELO MARCELINO MAGALHÃES

\section{Subjetividade em advir: a construção da metáfora em textos de alunos da escola básica}

Dissertação apresentada à Faculdade de Educação da Universidade de São Paulo para obtenção do título de Mestre em Educação.

Área de Concentração: Linguagem e Educação Orientadora: Profa. Dra. Claudia Rosa Riolfi 
Ao Luiz e
p(r)onto! 


\section{AGRADECIMENTOS}

A minha orientadora, Claudia Riolfi, pela multifuncionalidade que acabou desempenhando durante este mestrado. Pela orientação franca e rigorosa. Pela amizade que fica...

Ao Prof. Dr. Valdir Heitor Barzotto, pelos ricos ensinamentos sobre a pesquisa na área de Letras. Pelo exemplo de militância inteligente.

Aos colegas professores de Língua Portuguesa que colaboraram como interlocutores, fornecendo dados ou simplesmente fazendo torcida. Em especial, aos colegas Léo Batista e Hamilton Moreira Jr, da EE Esmeraldo S. T. de Campos Filho, em São Vicente - SP.

A todos os meus alunos da EE Esmeraldo S. T. de Campos Filho e do Colégio Integração, em São Vicente - SP, por disponibilizarem seus textos para esta pesquisa e pelos pontos de interrogação que botaram em minha cabeça, estopim para este trabalho.

Aos colegas de trabalho (que viraram amigos também) da Diretoria de Ensino de São Vicente (DERSV), pela interlocução, cumplicidade e apoio nos mais diversos aspectos: Rita Alves, Marília, Sérgio e Marcos.

Aos meus pais - Paulo e Solange, pelos subsídios que me permitiram chegar ao Mestrado. A minha irmã Zilah, pela parceria. Aos meus avós - Jacyra, pela presença constante e João Gomes, responsável pela minha inserção no mundo das letras.

Aos colegas do GEPPEP, parceiros para todas as horas.

À “turma do 309” - Emari, Edvan, Rosâgela e Cristiane - por me fazerem sentir em casa, me acolhendo todas as vezes que precisei dormir longe de casa, em função do Mestrado.

Aos amigos - Kátia e Arthur, Lindinete e Obede, Marceli e Edivan - pelo apoio operacional, por compreenderem minhas ausências e por incluírem e admitirem nas viagens e programas sociais, não só eu, mas meu corpus e meus livros.

Aos Profs. Drs. Rinaldo Voltolini e Marisa Grigoletto, pela leitura cuidadosa e pelas sugestões valiosas para a conclusão deste trabalho, por ocasião do exame de qualificação.

À Sonia, pela revisão rápida e cuidadosa. Ao Bruno Maroneze, pela ajuda com o inglês.

A Tata, minha cunhada, por ter partilhado algumas das minhas funções, sobretudo, na reta final.

À Secretaria de Educação do Estado de São Paulo, pela concessão da Bolsa Mestrado e à Dirigente Regional de Ensino de São Vicente - Serli Carvalho Rodrigues - pela acolhida na DERSV e pelo aprendizado advindo dos 30 meses de trabalho neste órgão. 


\section{FOLHA DE APROVAÇÃO}

Mical de Melo Marcelino Magalhães

Subjetividade em advir: a construção da metáfora em textos de alunos da escola básica.

Dissertação apresentada à Faculdade de Educação da Universidade de São Paulo para obtenção do título de Mestre.

Área de Concentração: Linguagem e Educação

Aprovado em:

Banca Examinadora

Profa. Dra. Claudia Rosa Riolfi (orientadora)

Faculdade de Educação, da Universidade de São Paulo

Assinatura:

Profa. Dra. Marisa Grigoletto

Faculdade de Filosofia Letras e Ciências Humanas, da Universidade de São Paulo

Assinatura:

Prof. Dr. Rinaldo Voltolini

Faculdade de Educação, da Universidade de São Paulo

Assinatura:

Prof. Dr. Claudemir Belintane (suplente)

Faculdade de Educação, da Universidade de São Paulo

Assinatura:

Profa. Dra. Anna Maria G. Carmagnani (suplente)

Faculdade de Filosofia Letras e Ciências Humanas, da Universidade de São Paulo

Assinatura: 


\section{Resumo:}

A presente pesquisa partiu de minha experiência como professora de Língua Portuguesa, sobretudo no que diz respeito ao ensino da escrita nas turmas de Ensino Fundamental. A partir da compreensão de que a metáfora é um índice de manifestação da subjetividade e da constatação de que este é um recurso lingüístico raramente utilizado pelos alunos, passei a interrogar-me sobre a possibilidade de que outros elementos lingüístico-discursivos (a que chamei de "embriões de metáfora") permitissem supor uma subjetividade latente, com o prognóstico de poder vir a manifestar se pela construção de metáforas criativas. Na existência dessa possibilidade, investiguei se essa "relação privilegiada com a linguagem" poderia significar uma etapa em direção ao bem escrever. Perseguindo estas questões, este trabalho teve como proposta estabelecer correlações entre a produção escrita de alguém e a possibilidade de manifestar-se como sujeito (na concepção de Jacques Lacan), assim como descrever, através da análise de textos escritos pelos alunos, os elementos que possam ser chamados "embriões de metáfora". Parti, então, da hipótese que eles podem vir a tornarem-se metáforas se receberem um cuidadoso investimento daquele que ensina escrever e, nesse sentido, o trabalho propôs-se ainda a auxiliar o professor de língua materna a estabelecer critérios que permitam localizá-los nas produções dos alunos. Dessa forma, além de olhar para os textos como via (ou não) de manifestação subjetiva, proponho uma reflexão acerca das condições de produção de texto no âmbito escolar, sobretudo no que diz respeito ao endereçamento que os mesmos recebem. Para realizar estas análises, parti de um corpus inicial de seiscentos e quarenta e oito redações, das quais quatro figuram nesta dissertação. A seleção destas peças deu-se pelo fato de que cada uma delas é emblemática ao representar quatro "graus" de relação do indivíduo que escreve com a linguagem. A análise destes textos, articulada com alguns conceitos da teoria lacaniana, permitiu-me, à título de conclusão deste trabalho, postular que as relações estabelecidas entre aquele que ensina a escrever e aquele que escreve precisam estar calcadas na permeabilidade daquele que ensina às singularidades de quem escreve, de modo que as aulas de Língua Portuguesa constituam espaços para que os sujeitos possam ousar manifestar sua diferença e responsabilizar-se por ela.

Unitermos: ensino da escrita, , subjetividade, metáfora, embriões de metáfora, 
Abstract:

This research has started from my experience as Portuguese Language teacher, especially concerning the teaching of writing in elementary school. With the understanding that metaphor is a sign of manifestation of subjectivity, and noticing that this is a linguistic resource seldom used by the students, I began to ask myself about the possibility that other linguistic/discoursive elements would make me suppose a latent subjectivity (called by me "metaphor embryo"), which would be able to manifest itself in the construction of creative metaphors. As this possibility really exists, I investigated whether this "privileged relationship to language" could mean a stage towards good writing. In pursuing these questions, this work had as its main goal to establish correlations between one's written production and his/her possibility of manifestation as a subject (in Jacques Lacan's conception), as well as to describe, through the analysis of texts written by the students, the elements which could be named "metaphor embryos". Starting from the hypothesis that these embryos can become metaphors if receive a careful treatment from the person who teaches writing, this work has also the goal of helping the mother language teacher in establishing criteria to find them in the students' compositions. In so doing, besides looking to the text as a way of subjective manifestation, I proppose a reflection on the text producing conditions in school environment. In order to make these analyses, I started from a corpus of six hundred forty-eight compositions, of which four figure in this dissertation. The choosing of these texts was due to the fact that each one of them is emblematic in representing four "degrees" of the relationship between the person who writes and the language. Articulating the analysis of these texts with some concepts of Lacan's theory, I postulate, as a conclusion, that the relationships established between the one who teaches to write and the one who writes need to be focused on the teacher's "permeability" to the student's singularities, in such a way that the Portuguese Language classes become spaces for the subjects to dare to manifest their difference and be responsible for it.

Keywords: writing teaching, subjectivity, metaphor, , metaphor embryos. 